\title{
Remdesivir and its antiviral activity against COVID-19: A systematic review
}

\author{
Andri Frediansyah ${ }^{\mathrm{a}, \mathrm{b},{ }^{* *}}$, Firzan Nainu ${ }^{\mathrm{c}}$, Kuldeep Dhama ${ }^{\mathrm{d}}$, Mudatsir Mudatsir ${ }^{\mathrm{e}, \mathrm{f}, \mathrm{g}}$, \\ Harapan Harapan e, f, g, *
}

${ }^{a}$ Research Division for Natural Product Technology (BPTBA), Indonesian Institute of Sciences (LIPI), Wonosari, 55861, Indonesia

${ }^{\mathrm{b}}$ Department of Pharmaceutical Biology, Pharmaceutical Institute, University of Tübingen, Tübingen, 72076, Germany

${ }^{\mathrm{c}}$ Faculty of Pharmacy, Hasanuddin University, Tamalanrea, Makassar, 90245, Indonesia

d Division of Pathology, ICAR-Indian Veterinary Research Institute, Izatnagar, Bareilly, 243122, Uttar Pradesh, India

${ }^{\mathrm{e}}$ Medical Research Unit, School of Medicine, Universitas Syiah Kuala, Banda Aceh, 23111, Indonesia

${ }^{\mathrm{f}}$ Tropical Disease Centre, School of Medicine, Universitas Syiah Kuala, Banda Aceh, 23111, Indonesia

${ }^{\mathrm{g}}$ Department of Microbiology, School of Medicine, Universitas Syiah Kuala, Banda Aceh, 23111, Indonesia

\section{A R T I C L E I N F O}

\section{Keywords:}

COVID-19

SARS-CoV-2

Treatment

Remdesivir

Clinical trial

\begin{abstract}
A B S T R A C T
Background: The aim of this study was to summarize the antiviral activities of remdesivir against SARS-CoV-2, the causative agent of COVID-19.

Methods: Available publications were systematically explored on some databases and gray literature was examined. Publications were discussed narratively.

Results: Remdesivir inhibits SARS-CoV-2 replication, reduces viral load, and exerts protective effects in SARSCoV-2 infected animals. Remdesivir also reduces the pathological process, alleviates mild symptoms, and improves pulmonary lesions in SARS-CoV-2-infecetd animals. Remdesivir has been used as a compassionate drug for treating COVID-19 patients.

Conclusion: Although remdesivir has shown potent antiviral activities, more efficacy assessments are urgently warranted in clinical trials.
\end{abstract}

\section{Introduction}

The current coronavirus disease 2019 (COVID-19) pandemic, has caused considerable challenges to the national healthcare systems of most affected countries. ${ }^{1,2}$ The most common clinical manifestations of COVID-19 include fever, cough, dyspnea, chest pain, and pneumonia with ground-glass opacities being the most common finding in computed tomography imaging. ${ }^{3,4}$ Aside from respiratory symptoms, COVID-19 could involve cardiac manifestations, ${ }^{5}$ the digestive system, ${ }^{6}$ and other organs. ${ }^{7-9}$ The progression and severity of COVID-19 may be associated with dysregulation of host immune responses. ${ }^{10}$ As on June 8, 2020, over 7 million confirmed COVID-19 cases and 400,000 deaths were reported, according to the COVID-19 Global Cases database. ${ }^{11}$ The rapid transmission of the virus is mainly owing to its high reproductive number $\left(\mathrm{R}_{0}\right)$, with a mean of $3.28,{ }^{12}$ implying that one infected person could transmit the virus to up to three unvaccinated individuals. The virus, severe acute respiratory syndrome coronavirus 2 (SARS-CoV-2), is a member of the family Coronaviridae and genus Betacoronavirus, together with SARS-CoV and Middle East respiratory syndrome-related coronavirus (MERS-CoV). ${ }^{8}$ The virus has $79.6 \%$ sequence similarity with SARS-CoV. ${ }^{13}$

A specific antiviral treatment for COVID-19 is yet to be identified; ${ }^{14}$ therefore, several strategies have been proposed to treat patients, including the use of convalescent plasma and interferon (IFN), as well as interleukin 6 receptor inhibitors since they have the potential to inhibit the cytokine storm. ${ }^{10}$ Chloroquine and hydroxychloroquine that inhibit endocytosis-mediated viral entry, inhibit endosomal acidification, and disrupt glycosylation of angiotensin converting enzyme 2 (ACE2), ${ }^{15-18}$ as well as ivermectin that inhibits nuclear transport of viral proteins, ${ }^{19,20}$ have been used to treat COVID-19. In addition, antivirals that inhibit protease inhibitors ${ }^{21-25}$ and nucleotide or nucleoside analogs that inhibit viral RNA synthesis ${ }^{17,26-28}$ have been repurposed for the

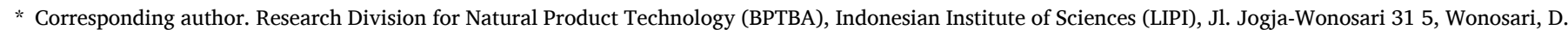
I, Yogyakarta, 55861, Indonesia.

** Corresponding author. Medical Research Unit, School of Medicine, Universitas Syiah Kuala, Jl. T. Tanoeh Abe, Darussalam, Banda Aceh, 23111, Indonesia.

E-mail addresses: andri.frediansyah@lipi.go.id (A. Frediansyah), firzannainu@unhas.ac.id (F. Nainu), kdhama@rediffmail.com (K. Dhama), mudatsir@unsyiah. ac.id (M. Mudatsir), harapan@unsyiah.ac.id (H. Harapan). 
treatment of the SARS-CoV-2 infection. Nucleoside analogs represent a group of drugs that inhibit reverse transcription and are among the most potent antiviral agents available to combat the SARS-CoV-2 infection-within this group is remdesivir. The objective of this review was to summarize evidence from in vitro studies, in vivo studies, use in patients with COVID-19 under emergency protocol, and clinical trials to provide comprehensive information on the potential of remdesivir in the treatment of patients with COVID-19.

\section{Materials and methods}

Relevant articles were searched on PubMed and Google Scholar using the search terms "remdesivir", AND "coronavirus", OR "SARSCoV", OR "MERS-CoV", OR "SARS-CoV-2" in the title and abstract. Recent clinical trials assessing the efficacy of remdesivir against COVID19 were also searched on the ClinicalTrials.gov database. The screened publications were classified and analyzed based on the study types: in
ACE2 receptor
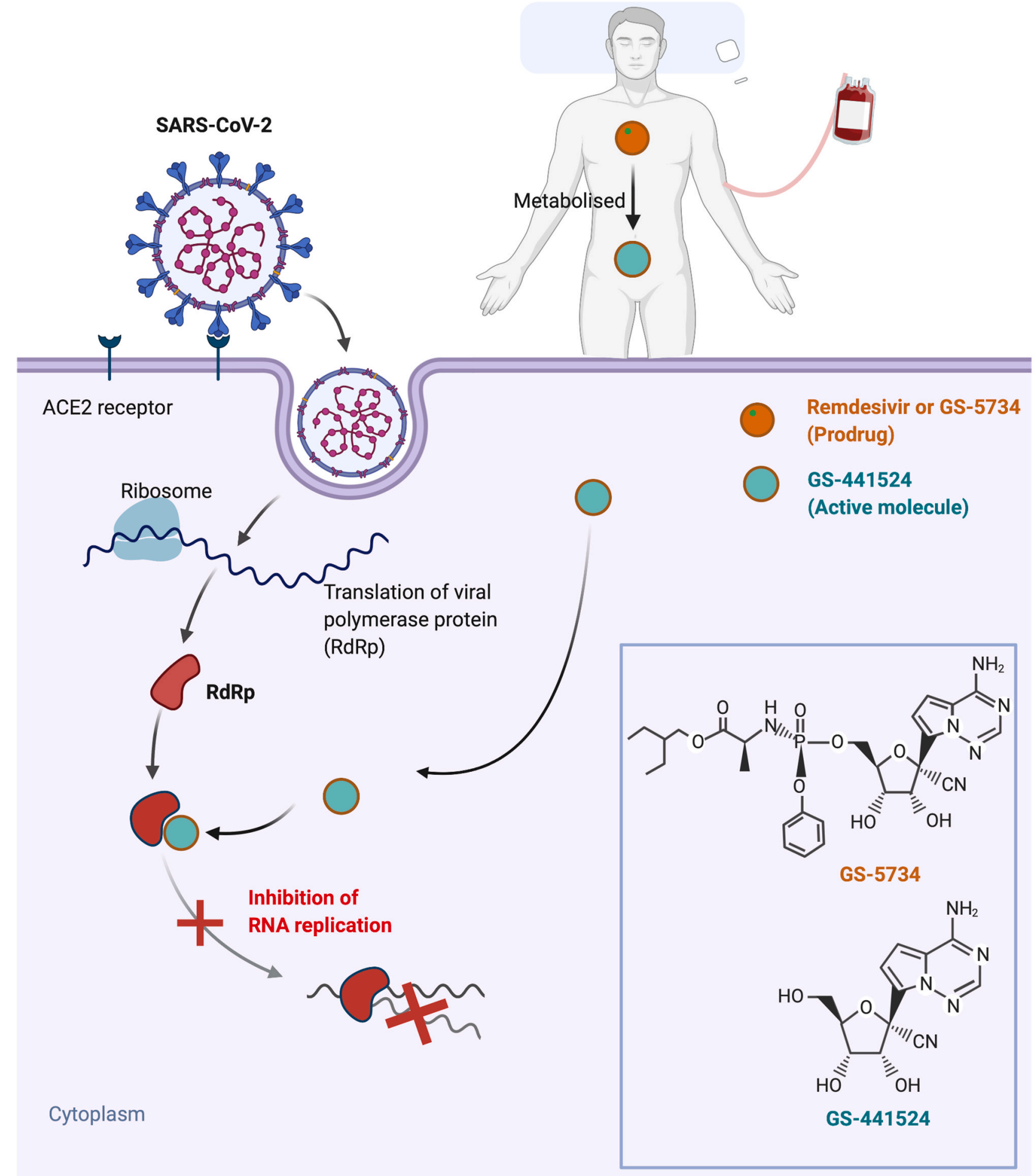

Fig. 1. Structure and mechanism of action of remdesivir (GS-5734) and its pharmacological active form (GS-441524). 
vitro, in vivo, emergency use in hospitals, and clinical trials. All available articles until May 4, 2020 were considerate eligible.

\section{Results}

The search combinations yielded 21 main references related to remdesivir. Antiviral activity and mechanism of remdesivir in both nonand coronaviruses have been reported in several in vitro studies. ${ }^{17,29-39}$ In vivo studies have been conducted to assess antiviral effect of remdesivir on non-coronaviruses using rhesus monkeys ${ }^{30}$ and African green monkeys ${ }^{40}$ as well as on coronavirus such as in mice ${ }^{34,41}$ and rhesus macaques. ${ }^{42,43}$ The antiviral effect of remdesivir also have been assessed in humans ${ }^{44}$ and it have been used to treat severe COVID-19 patients, as an emergency use. ${ }^{45-47}$ Although only one clinical trial has been conducted to assess the effectiveness and safety of remdesivir for COVID-19, ${ }^{48}$ several clinical trials are ongoing in some countries.

\section{Discussion}

\subsection{Remdesivir: an introduction}

Remdesivir (GS-5734; Gilead Sciences Inc., US) is an investigational nucleoside analog that acts as a competitive inhibitor of viral RNAdependent RNA polymerase (RdRp) (Fig. 1). ${ }^{13}$ It is a prodrug with a molecular formula of $\mathrm{C}_{27} \mathrm{H}_{35} \mathrm{~N}_{6} \mathrm{O}_{8} \mathrm{P}$ and an exact mass of $602.23 \mathrm{Da}$. In the body, remdesivir is transformed into an active molecule known as GS-441524 (Fig. 1), with a molecular formula of $\mathrm{C}_{12} \mathrm{H}_{13} \mathrm{~N}_{5} \mathrm{O}_{4}(291.10$ Da). Remdesivir was previously proposed for the treatment of Ebola $^{29,30,44}$ and is yet to be approved or licensed by the US Food and Drug Administration (FDA) or any other drug regulatory authority worldwide. The antiviral activities of remdesivir on RdRp have been reported against Ebola virus, ${ }^{36,37}$ MERS-CoV, ${ }^{33}$ SARS-CoV, ${ }^{33,34}$ and other coronaviruses such as CoV-OC43, CoV-229E, and PDCoV. ${ }^{35}$

\subsection{Evidence from in vitro studies}

In 2015, a study showed that remdesivir is an effective inhibitor of the Ebola virus. ${ }^{29}$ Its half-maximal effective concentration $\left(\mathrm{EC}_{50}\right)$, the drug concentration that induces a response halfway between the baseline and maximum after a specified exposure time, varied between 0.07 and $0.14 \mu \mathrm{M}$ in Ebola-infected cells such as HeLa, HFF-1, HMVEC-TERT, and Huh-7. ${ }^{30}$ Studies on the inhibitory effects of remdesivir against various viruses have been conducted using seven virus families, namely, filo-, paramyxo-, pneumo-, bunya-, arena-, rhabdo-, and flaviviruses. ${ }^{31}$ Another study showed that phosphorylated GS-441524, the active molecule of remdesivir, inhibited feline infectious peritonitis in CRFK cells, with a half maximal inhibitory concentration ( $\mathrm{IC}_{50}$; the drug concentration at which half of the peak inhibiting effect of the drug against a specific viral function is achieved) of $0.78 \mu \mathrm{M} .^{32} \mathrm{The} \mathrm{EC}_{50}$ of remdesivir against the murine hepatitis virus is $0.03 \mu \mathrm{M} .{ }^{33}$ Remdesivir also exerts antiviral activities against MERS-CoV, Junin virus, and Lassa fever virus in HeLa cells, with $\mathrm{EC}_{50}$ values of $0.34,0.47$, and $1.48 \mu \mathrm{M}$, respectively. ${ }^{30}$ Another study revealed that remdesivir inhibits SARS-CoV and MERS-CoV in human airway epithelial (HAE) cells, with $\mathrm{EC}_{50}$ values of 0.069 and $0.074 \mu \mathrm{M}$, respectively. ${ }^{34}$ The summary of the $\mathrm{EC}_{50}$ and $\mathrm{IC}_{50}$ of remdesivir and its active component GS-441524 against highly pathogenic human coronaviruses (MERS-CoV and SARS-CoV) is presented in Table 1.

Remdesivir inhibits RdRp; its antiviral activity against RdRp has been reported in Huh7 human cells infected with CoV-OC43, CoV-229E, and $\mathrm{PDCoV}$, with $\mathrm{EC}_{50}$ values ranging between 0.02 and $0.17 \mu \mathrm{M} .{ }^{35}$ The same mechanism, i.e., the inhibition of RdRp, has also been reported in Ebola virus. ${ }^{36,37}$ In 2020, a study revealed that the inhibitory mechanism of the active triphosphate molecule of remdesivir against MERS-CoV in insect cells involved various nonstructural proteins (nsp), such as nsp5, nsp7, nsp8, and nsp12 (RdRp). ${ }^{38}$
Table 1

In vitro studies on efficacy of remdesivir and its active component against highly pathogenic Coronaviruses (MERS-CoV, SARS-CoV, and SARS-CoV-2).

\begin{tabular}{lllll}
\hline Component & Virus & Cell line & IC $_{50}$ or $\mathrm{EC}_{50}$ & Reference \\
\hline Remdesivir & MERS-CoV & Calu-3 2B4 & $\mathrm{IC}_{50}=0.025 \mu \mathrm{M}^{\mathrm{a}}$ & 34 \\
& & HAE & $\mathrm{IC}_{50}=0.074 \mu \mathrm{M}^{\mathrm{a}}$ & 34 \\
& & Calu-3 2B4 & $\mathrm{EC}_{50}=0.09 \mu \mathrm{M}^{\mathrm{a}}$ & 41 \\
& & HAE & $\mathrm{EC}_{50}=0.07 \mu \mathrm{M}^{\mathrm{a}}$ & 33 \\
& SARS-CoV & HAE & $\mathrm{IC}_{50}=0.069 \mu \mathrm{M}^{\mathrm{a}}$ & 34 \\
& SARS-CoV-2 & Vero E6 & $\mathrm{EC}_{50}=0.07 \mu \mathrm{M}^{\mathrm{a}}$ & 33 \\
& & Vero E6 & $\mathrm{EC}_{50}=0.77 \mu \mathrm{M}^{\mathrm{a}}$ & 17 \\
& & HAE & $\mathrm{EC}_{50}=0.86 \mu \mathrm{M}^{\mathrm{a}}$ & 39 \\
GS-441524 & MERS-CoV & HAE & $\mathrm{EC}_{50}=0.18 \mu \mathrm{M}^{\mathrm{a}}$ & 33 \\
& SARS-CoV & HAE &
\end{tabular}

Calu-3: human bronchial epithelial cells; HAE: human airway epithelial cells; MERS-CoV: Middle East respiratory syndrome-related coronavirus; SARS-CoV-2: The virus, severe acute respiratory syndrome coronavirus 2; SARS-CoV: severe acute respiratory syndrome-related coronavirus; Vero E6: African green monkey kidney epithelial cells.

a The viral load was fit in a linear scale (the percentage of inhibition) under increasing concentrations of remdesivir or GS-441524.

b The viral load was fit in a logarithmic scale $\left(\log _{10} \mathrm{TCID}_{50} / \mathrm{mL}\right.$ and $\log _{10}$ viral RNA copies/mL) under increasing concentrations of remdesivir.

The RdRp sequences of SARS-CoV-2 and SARS-CoV display more than $80 \%$ similarity. ${ }^{49,50}$ Therefore, it was suggested that remdesivir could potentially exert antiviral activities against SAR-CoV-2. Remdesivir was found to have an $\mathrm{EC}_{50}$ of 0.77 against SARS-CoV-2 in Vero E6 cells (Table 1). ${ }^{17}$ This activity of remdesivir was higher than that of the other drugs used in the study, such as ribavirin, penciclovir, favipiravir, nafamostat, nitazoxanide, and chloroquine, which showed $\mathrm{EC}_{50}$ values of $109.5,95.96,61.88,22.50,2.12$, and $1.13 \mu \mathrm{M}$, respectively. ${ }^{17}$ Another study in Vero E6 cells also revealed that remdesivir inhibited the replication of SARS-CoV-2, with an $\mathrm{EC}_{50}$ of $23.15 \mu \mathrm{M}$, showing the strongest antiviral activity among the tested drugs. ${ }^{39}$ In this study, the viral load was fit in a logarithmic scale under increasing remdesivir concentrations, rather than a linear scale reported previously. ${ }^{17}$ These initial studies suggest that remdesivir inhibits the replication of SARS-CoV-2 and has the potential to be used in the treatment of COVID-19.

\subsection{Evidence from in vivo studies}

In 2016, an in vivo study was conducted using Ebola-infected rhesus monkeys (a non-human primate) and various doses of remdesivir intramuscular injections. ${ }^{30}$ Post-exposure revealed that remdesivir exerted protective effects by inhibiting viral replication. ${ }^{30}$ The concentration of form of remdesivir, was $10 \mu \mathrm{M}$ in peripheral blood mononuclear cells after administration of $10 \mathrm{mg} / \mathrm{kg}$ remdesivir. ${ }^{30} \mathrm{~A}$ study in Nipah virus-infected African green monkeys showed the protective effects of remdesivir: half of the remdesivir-treated monkeys $(n=4)$ developed mild respiratory symptoms and the other half recovered; those in the control group developed severe respiratory disease. ${ }^{40}$

Remdesivir has also been shown to exert antiviral activity against coronaviruses. Remdesivir treatment was found to reduce the viral load in MERS-CoV-infected Ces1c ${ }^{-/-}$hDPP4 mice and was phenotypically associated with improved pulmonary function and decreased likelihood of acute lung injury development in infected animals. ${ }^{41}$ In addition, remdesivir inhibited MERS-CoV replication in the pulmonary organs of rhesus macaques and led to a reduction in lung lesions. ${ }^{42}$ Remdesivir also reduced the viral load in the lung and improved the respiratory function of SARS-CoV MA15-infected mice. ${ }^{34}$ A recent study showed that remdesivir administration to SARS-CoV-2-infected rhesus macaques improved pulmonary lesions, according to radiographs; reduced viral titers in bronchoalveolar lavage after $12 \mathrm{~h}$ of treatment; and reduced the viral load in the lungs after 7 days of treatment. Moreover, the remdesivir-treated animals did not show any signs of pulmonary disease. ${ }^{43}$ 


\subsection{Results from patients with COVID-19 and clinical trials}

Historically, remdesivir was tested to treat patients with Ebola in a randomized clinical trial in the Democratic Republic of the Congo in $2018 .{ }^{44}$ In 2020, remdesivir was included in the "Solidarity" international clinical trial conducted by the World Health Organization in an attempt to find an effective treatment for COVID-19. ${ }^{51}$ As a timely response to the pandemic, patients with COVID-19 have been treated with remdesivir in emergency protocols. In the first patient with COVID-19 treated with remdesivir, a 35-year-old from Washington, pneumonia improved after 7 days of treatment. ${ }^{45}$ In Seattle, USA, remdesivir was used as a compassionate drug to treat seven critically ill patients. ${ }^{46}$ A larger study found that, following a 10-day course of remdesivir treatment (intravenous administration at $200 \mathrm{mg}$ on day 1 , followed by $100 \mathrm{mg}$ daily), 68\% (36 of 53) of patients with COVID-19 showed clinical improvement; however, there was no control group in this study. ${ }^{47}$ Therefore, this information is insufficient to confirm the efficacy of remdesivir in treating patients with COVID-19.

To adequately assess the efficacy of remdesivir, clinical trials are ongoing in countries such as USA, Norway, Canada, France, and China. A list of currently ongoing clinical trials has been presented in Table 2. Although the length of treatment differs slightly, the dose of remdesivir is similar: $200 \mathrm{mg}$ on day 1 , followed by $100 \mathrm{mg}$ for the rest of the treatment period.

The first randomized, double-blind, placebo-controlled, multicenter clinical trial was reported on April 29, 2020. ${ }^{48}$ The study was conducted in China with 237 patients (158 in the remdesivir group and 79 in the placebo control group), and the primary endpoint was the time taken to achieve clinical improvement. The study revealed that treatment with remdesivir did not lead to a significant reduction in the time taken to achieve clinical improvement. In addition, mortality and viral clearance time in patients with severe COVID-19 were not significantly different from those in the placebo group, suggesting that remdesivir had poor clinical benefits. This further suggests that in COVID-19, viral propagation is not the main factor responsible for disease severity. On this account, the antiviral properties of remdesivir will not be beneficial. The severity of COVID-19 has been associated with the cytokine release storm, ${ }^{52}$ suggesting that host immune responses play an important role in this event. Therefore, a combination of remdesivir with immunosuppressants (for example sarilumab, an IL-6 the inhibitor) and/or other antiviral agents might potentiate the antiviral activity of remdesivir and mitigate the immunopathological injury caused by excessive immune effectors. $^{52}$

Nonetheless, during the same trial, ${ }^{52}$ in remdesivir-treated patients with COVID-19, especially those treated within 10 days of symptom onset, faster clinical improvement was observed than that in the placebo group. Unfortunately, the study was terminated prematurely owing to the occurrence of more frequent adverse events in the remdesivir group than in the placebo group. ${ }^{52}$ Considering these findings, the small sample size, and because the study was unexpectedly terminated, it may be insufficient to elucidate the efficacy of remdesivir. ${ }^{53}$ Furthermore, the pharmacokinetics of remdesivir and its active metabolite in the respiratory tracts and/or other infected organs remain largely unknown in patients with COVID-19. ${ }^{36}$ Therefore, the results of ongoing clinical trials (Table 1) are warranted to provide conclusive evidence regarding the efficacy of remdesivir in patients with COVID-19.

The pharmacokinetic profile of remdesivir, particularly the concentrations of the active metabolite, GS-441524, in the respiratory tract or other infected tissues in patients with severe COVID-19 are unknown. ${ }^{48}$ In addition, currently available data on remdesivir are lacking, in particular those in drug-drug, drug-gene, and drug-disease interactions. This information is important in predicting possible negative outcomes that may arise during treatment.
Table 2

A list of ongoing clinical trials of remdesivir registered on ClinicalTrial.gov.

\begin{tabular}{|c|c|c|c|c|}
\hline $\begin{array}{l}\text { Identifier } \\
\text { number }\end{array}$ & Title & $\begin{array}{l}\text { Expected } \\
\text { participants }\end{array}$ & $\begin{array}{l}\text { Length of } \\
\text { treatment }\end{array}$ & Location \\
\hline NCT04292899 & $\begin{array}{l}\text { Study to evaluate } \\
\text { the safety and } \\
\text { antiviral activity of } \\
\text { remdesivir (GS- } \\
5734^{\mathrm{TM}} \text { ) in } \\
\text { participants with } \\
\text { severe coronavirus } \\
\text { disease (COVID-19) }\end{array}$ & 6000 & $\begin{array}{l}\text { 5-10 days } \\
\text { (and } \\
\text { possibly } \\
\text { extension) }\end{array}$ & USA \\
\hline NCT04292730 & $\begin{array}{l}\text { Study to evaluate } \\
\text { the safety and } \\
\text { antiviral activity of } \\
\text { remdesivir (GS- } \\
5734^{\mathrm{TM}} \text { ) in } \\
\text { participants with } \\
\text { moderate } \\
\text { coronavirus disease } \\
\text { (COVID-19) } \\
\text { compared to } \\
\text { standard of care } \\
\text { treatment }\end{array}$ & 1600 & $\begin{array}{l}\text { 5-10 days } \\
\text { (and } \\
\text { possibly } \\
\text { extension) }\end{array}$ & USA \\
\hline NCT04321616 & $\begin{array}{l}\text { The efficacy of } \\
\text { different antiviral } \\
\text { drugs in COVID } 19 \\
\text { infected patients }\end{array}$ & 700 & 10 days & Norway \\
\hline NCT04330690 & $\begin{array}{l}\text { Treatments for } \\
\text { COVID-19: } \\
\text { Canadian Arm of } \\
\text { the Solidarity Trial } \\
\text { (CATCO) }\end{array}$ & 440 & 9 days & Canada \\
\hline NCT04280705 & $\begin{array}{l}\text { Adaptive COVID-19 } \\
\text { treatment Trial } \\
\text { (ACTT) }\end{array}$ & 800 & 10 days & USA \\
\hline NCT04315948 & $\begin{array}{l}\text { Trial of treatments } \\
\text { for COVID-19 in } \\
\text { hospitalized adults } \\
\text { (DisCoVeRy) }\end{array}$ & 3100 & 10 days & France \\
\hline NCT04349410 & $\begin{array}{l}\text { The Fleming } \\
\text { [FMTVDM] } \\
\text { directed CoVid-19 } \\
\text { treatment protocol }\end{array}$ & 500 & 10 days & USA \\
\hline NCT04365725 & $\begin{array}{l}\text { Multicenter, } \\
\text { retrospective study } \\
\text { of the effects of } \\
\text { remdesivir in the } \\
\text { treatment of severe } \\
\text { covid-19 infections } \\
\text { (REMDECO-19) }\end{array}$ & 200 & 15 days & France \\
\hline
\end{tabular}

\section{Conclusion}

Remdesivir is a nucleotide analog prodrug that inhibits SARS-CoV-2 RdRp. Its viral activities against SARS-CoV-2 have been shown in both in vitro and in vivo studies. Remdesivir has been used in several countries as an emergency drug for patients with COVID-19, and some patients showed improved clinical outcomes. However, large-scale clinical trials should be conducted to confirm the efficacy of remdesivir in treating patients with COVID-19.

\section{Authors' contributions}

$\mathrm{AF}$ and $\mathrm{HH}$ conceived and designed the study. $\mathrm{AF}, \mathrm{FN}$, and $\mathrm{HH}$ were responsible for data collection. $\mathrm{AF}$ and $\mathrm{HH}$ wrote the initial manuscript. $\mathrm{KD}, \mathrm{MM}$, and $\mathrm{HH}$ critically revised the manuscript. All authors have read the final manuscript.

\section{Declaration of competing interest}

The authors declare that they have no competing interests. 


\section{References}

1 Rodriguez-Morales AJ, Cardona-Ospina JA, Gutierrez-Ocampo E, et al. Clinical, laboratory and imaging features of COVID-19: a systematic review and metaanalysis. Trav Med Infect Dis. 2020;34:101623.

2 Armocida B, Formenti B, Ussai S, Palestra F, Missoni E. The Italian health system and the COVID-19 challenge. Lancet Public Health. 2020;5(5):e253.

3 Sahu KK, Lal A, Mishra AK. An update on CT chest findings in coronavirus disease-19 (COVID-19). Heart Lung. 2020. https://doi.org/10.1016/j.hrtlng.2020.03.007 (In press).

4 Hosseiny M, Kooraki S, Gholamrezanezhad A, Reddy S, Myers L. Radiology perspective of coronavirus disease 2019 (COVID-19): lessons from severe acute respiratory syndrome and Middle East respiratory syndrome. AJR Am J Roentgenol. 2020;214(5):1078-1082.

5 Mishra AK, Sahu KK, George AA, Lal A. A review of cardiac manifestations and predictors of outcome in patients with COVID-19. Heart Lung. 2020. https://doi.org/ 10.1016/j.hrtlng.2020.04.019 (In press).

6 Mao R, Qiu Y, He JS, et al. Manifestations and prognosis of gastrointestinal and liver involvement in patients with COVID-19: a systematic review and meta-analysis. Lancet Gastroenterol Hepatol. 2020;5(7):667-678.

7 Benny R, Khadilkar SV. COVID 19: neuromuscular manifestations. Ann Indian Acad Neurol. 2020;23(Suppl 1):S40-S42.

8 Harapan H, Itoh N, Yufika A, et al. Coronavirus disease 2019 (COVID-19): a literature review. J Infect Public Health. 2020;13(5):667-673.

$9 \mathrm{Wu}$ Z, McGoogan JM. Characteristics of and important lessons from the coronavirus disease 2019 (COVID-19) outbreak in China: summary of a report of 72314 cases from the Chinese center for disease control and prevention. J Am Med Assoc. 2020; 323(13):1239-1242.

10 Keam S, Megawati D, Patel S, Tiwari R, Dhama K, Harapan H. Immunopathology and immunotherapeutic strategies in SARS-CoV-2 infection. Rev Med Virol. 2020. https:// doi.org/10.1002/rmv.2123 (In press).

11 Dong E, Du H, Gardner L. An interactive web-based dashboard to track COVID-19 in real time. Lancet Infect Dis. 2020;20(5):533-534.

12 Liu Y, Gayle A, Wilder-Smith AJR. The reproductive number of COVID-19 is higher compared to SARS coronavirus. J Trav Med. 2020;27(2), taaa021.

13 Zhou P, Yang XL, Wang XG, et al. A pneumonia outbreak associated with a new coronavirus of probable bat origin. Nature. 2020;579(7798):270-273.

14 Cascella M, Rajnik M, Cuomo A, Dulebohn SC, Di Napoli R. Features, Evaluation and Treatment Coronavirus (COVID-19). Statpearls: StatPearls Publishing; 2020.

15 Liu J, Cao R, Xu M, et al. Hydroxychloroquine, a less toxic derivative of chloroquine, is effective in inhibiting SARS-CoV-2 infection in vitro. Cell Discovery. 2020;6(1):16.

16 Gao J, Tian Z, Yang X. Breakthrough: chloroquine phosphate has shown apparent efficacy in treatment of COVID-19 associated pneumonia in clinical studies. BioScience Trends. 2020;14(1):72-73.

17 Wang M, Cao R, Zhang L, et al. Remdesivir and chloroquine effectively inhibit the recently emerged novel coronavirus (2019-nCoV) in vitro. Cell Res. 2020;30(3): 269-271.

18 Colson P, Rolain J-M, Raoult D. Chloroquine for the 2019 novel coronavirus SARSCoV-2. Int J Antimicrob Agents. 2020;55(3), 105923.

19 Caly L, Druce JD, Catton MG, Jans DA, Wagstaff KM. The FDA-approved drug ivermectin inhibits the replication of SARS-CoV-2 in vitro. Antivir Res. 2020;178, 104787.

20 Choudhary R, Sharma AK. Potential use of hydroxychloroquine, ivermectin and azithromycin drugs in fighting COVID-19: trends, scope and relevance. New Microbes New Infect. 2020;23, 100684.

21 Wang J. Fast identification of possible drug treatment of coronavirus disease-19 (COVID-19) through computational drug repurposing study. J Chem Inf Model. 2020; 60(6):3277-3286. https://doi.org/10.1021/acs.jcim.0c00179.

22 Liu X, Wang X-J. Potential inhibitors against 2019-nCoV coronavirus M protease from clinically approved medicines. J Genet Genomics. 2020;47(2):119-121. https:// doi.org/10.1021/acs.jcim.0c00179.

23 McKee DL, Sternberg A, Stange U, Laufer S, Naujokat C. Candidate drugs against SARS-CoV-2 and COVID-19. Pharmacol Res. 2020;157, 104859.

24 Hall Jr DC, Ji HF. A search for medications to treat COVID-19 via in silico molecular docking models of the SARS-CoV-2 spike glycoprotein and 3CL protease. Trav Med Infect Dis. 2020;35, 101646. https://doi.org/10.1016/j.tmaid.2020.101646.

25 Zhua Z, Luc Z, Xud T, et al. Arbidol monotherapy is superior to lopinavir/ritonavir in treating COVID-19. J Infect. 2020;81(1):e21-e23.
26 Elfiky AA. Ribavirin, remdesivir, sofosbuvir, galidesivir, and tenofovir against SARSCoV-2 RNA dependent RNA polymerase (RdRp): a molecular docking study. Life Sci. 2020;253, 117592-117592.

27 Martinez MA. Compounds with therapeutic potential against novel respiratory 2019 coronavirus. Antimicrob Agents Chemother. 2020;64. e00399-20.

$28 \mathrm{Wu}$ F, Zhao S, Yu B, et al. A new coronavirus associated with human respiratory disease in China. Nature. 2020;579:265-269.

29 Warren T, Jordan R, Lo M, et al. Nucleotide prodrug GS-5734 is a broad-spectrum filovirus inhibitor that provides complete therapeutic protection against the development of Ebola virus disease (EVD) in infected non-human primates. Open Forum Infect Dis. 2015;2(suppl 1_1). LB-2.

30 Warren TK, Jordan R, Lo MK, et al. Therapeutic efficacy of the small molecule GS5734 against Ebola virus in rhesus monkeys. Nature. 2016;531(7594):381-385.

31 Lo MK, Jordan R, Arvey A, et al. GS-5734 and its parent nucleoside analog inhibit Filo-, Pneumo-, and Paramyxoviruses. Sci Rep. 2017;7:43395.

32 Murphy BG, Perron M, Murakami E, et al. The nucleoside analog GS-441524 strongly inhibits feline infectious peritonitis (FIP) virus in tissue culture and experimental cat infection studies. Vet Microbiol. 2018;219:226-233.

33 Agostini ML, Andres EL, Sims AC, et al. Coronavirus susceptibility to the antiviral remdesivir (GS-5734) is mediated by the viral polymerase and the proofreading exoribonuclease. mBio. 2018;9(2). e00221-00218.

34 Sheahan TP, Sims AC, Graham RL, et al. Broad-spectrum antiviral GS-5734 inhibits both epidemic and zoonotic coronaviruses. Sci Transl Med. 2017;9(396), eaal3653.

35 Brown AJ, Won JJ, Graham RL, et al. Broad spectrum antiviral remdesivir inhibits human endemic and zoonotic deltacoronaviruses with a highly divergent RNA dependent RNA polymerase. Antivir Res. 2019;169, 104541.

36 Tchesnokov EP, Feng JY, Porter DP, Gotte M. Mechanism of inhibition of Ebola virus RNA-dependent RNA polymerase by remdesivir. Viruses. 2019;11(4):326.

37 Tchesnokov EP, Raeisimakiani P, Ngure M, Marchant D, Gotte M. Recombinant RNAdependent RNA polymerase complex of Ebola virus. Sci Rep. 2018;8(1):1-9.

38 Gordon CJ, Tchesnokov EP, Feng JY, Porter DP, Gotte M. The antiviral compound remdesivir potently inhibits RNA-dependent RNA polymerase from Middle East respiratory syndrome coronavirus. J Biol Chem. 2020;295(15):4773-4779.

39 Choy K-T, Wong AY-L, Kaewpreedee P, et al. Remdesivir, lopinavir, emetine, and homoharringtonine inhibit SARS-CoV-2 replication in vitro. Antivir Res. 2020;178, 104786.

40 Lo MK, Feldmann F, Gary JM, et al. Remdesivir (GS-5734) protects African green monkeys from Nipah virus challenge. Sci Transl Med. 2019;11(494), eaau9242.

41 Sheahan TP, Sims AC, Leist SR, et al. Comparative therapeutic efficacy of remdesivir and combination lopinavir, ritonavir, and interferon beta against MERS-CoV. Nat Commun. 2020;11(1):1-14.

42 de Wit E, Feldmann F, Cronin J, et al. Prophylactic and therapeutic remdesivir (GS5734) treatment in the rhesus macaque model of MERS-CoV infection. Proc Natl Acad Sci USA. 2020;117(12):6771-6776.

43 Williamson B, Feldmann F, Schwarz B, et al. Clinical benefit of remdesivir in rhesus macaques infected with SARS-CoV-2. Nature. 2020. https://doi.org/10.1038/ s41586-020-2423-5 (In press).

44 Mulangu S, Dodd LE, Davey Jr RT, et al. A randomized, controlled trial of Ebola virus disease therapeutics. N Engl J Med. 2019;381(24):2293-2303.

45 Holshue ML, DeBolt C, Lindquist S, et al. First case of 2019 novel coronavirus in the United States. N Engl J Med. 2020;382(10):929-936.

46 Bhatraju PK, Ghassemieh BJ, Nichols M, et al. Covid-19 in critically ill patients in the Seattle region-case series. N Engl J Med. 2020;382(21):2012-2022.

47 Grein J, Ohmagari N, Shin D, et al. Compassionate use of remdesivir for patients with severe Covid-19. N Engl J Med. 2020;382(24):2327-2336.

48 Wang Y, Zhang D, Du G, et al. Remdesivir in adults with severe COVID-19: a randomised, double-blind, placebo-controlled, multicentre trial. Lancet. 2020;395 (10236):1569-1578.

49 Shannon A, Le NTT, Selisko B, et al. Remdesivir and SARS-CoV-2: structural requirements at both nsp12 RdRp and nsp14 Exonuclease active-sites. Antivir Res. 2020;178, 104793

50 Liu W, Morse JS, Lalonde T, Xu S. Learning from the past: possible urgent prevention and treatment options for severe acute respiratory infections caused by $2019-\mathrm{nCoV}$. Chembiochem. 2020;21(5):730-738.

51 WHO. Solidarity Clinical Trial for COVID-19 Treatments. 2020.

52 Soy M, Keser G, Atagündüz P, Tabak F, Atagündüz I, Kayhan S. Cytokine storm in COVID-19: pathogenesis and overview of anti-inflammatory agents used in treatment. Clin Rheumatol. 2020;39(7):2085-2094.

53 Norrie JD. Remdesivir for COVID-19: challenges of underpowered studies. Lancet. 2020;395:1569-1572. 